\title{
Over Vogelgeluiden
}

DOOR

\author{
JAG. P. THYSSE.
}

\begin{abstract}
Tusschen vogelgezang en vogelroep is geen scherp onderscheid te maken. Evenmin gaat het aan, om de geluiden, voortgebracht door leden van de orde der zangvogels te scheiden van die der andere soorten. Dit is niet alleen een kwestie van smaak. Er zijn steltloopers, wier geluiden in schoonheid en verscheidenheid de vergelijking met menigen zangvogel gerust kunnen doorstaan. Men denke slechts aan de wulp; de tureluur, den boschruiter en den oeverlooper. Zelfs het waterhoentje en de wijfjesbergeend roepen op sommige oogenblikken de herinnering aan den nachtegaal wakker. Wanneer we dieper wenschen te gaan en de vogelgeluiden bestudeeren naar hun ontstaan en beteekenis, dan dienen ook beschouwd te worden de geluiden der overige dieren, zoowel gewervelde als ongewervelde. Tusschen het roepen van onze groene specht en het brieschen van een paard bestaat meer verband, dan alleen de oppervlakkige gelijkenis. Ook is het aantal zingende zoogdieren grooter dan men gewoonlijk meent; de serenades en nocturnes van ratten en muizen verdienen meer belangstelling, dan zij tot nu toe genoten.

Intusschen is de studie van de vogelgeluiden het aantrekkelijkst en ook het gemakkelijkst, ofschoon de bezwaren eraan verbonden van dien aard zijn, dat we voorloopig nog niet kunnen verwachten, op eenigerlei wijze te geraken tot een samenvatting of een systeem. De geheele terminologie ligt nog in windselen en een vaste documenteering lijkt nog niet goed uitvoerbaar. De groote moeilijkheid ligt hierin, dat de vogelgeluiden maar al te dikwijls afwijken van onze gearticuleerde taal en van het vrij beperkt systeem van tonen en rhytmen, dat ten grondslag ligt aan onze muzikale genietingen, onze muzikale ontwikkeling. Zoolang dan ook de auteurs de vogelgeluiden waardeerden in termen van menschelijke taal en muziek, konden zij er geen recht wan doen wedervaren en zoo verheffen de beschrijvingen van Gilbert White, van Naumann en anderen zich dan ook weinig of niet boven de enkele klanknabootsende frasen, die de volksmond omtrent sommige vogels in omloop heeft gebracht.

Natuurlijk lag het voor de hand, om te trachten het vogellied vast te leggen in notenschrift. Deze methode kan echter slechts in bepaalde gevallen worden toegepast en dan nog alleen bij benadering. Er zijn niet veel intervallen-zangers. De meest bekende solfègezanger is de koekoek, waarvan men over het algemeen aanneemt, dat hij meestal een groote terts, dikwijls ook een kleine terts zingt. Maar wanneer men er maar genoeg hoort, komen allerlei intervallen te voorschijn, van seconde tot octaaf toe en dan nog meestal trots alle welluidendheid nog tamelijk valsch. Ook accentueert hij verschillend: nu eens op den eersten, dan weer op den tweeden toon. De koekoek-éénzang blijkt nog in andere opzichten sterk te varieeren, ook in het aantal tonen van het motief, ik noteerde zeer dikwijls drie tonen, zeldzamer meer, tot twaalf toe. Het drukke lied van het wijfje is moeilijk te ontcijferen.

Andere intervallen-zangers zijn de lijsters en de meezen. Verscheidene van hun motieven zijn genoteerd in "The Evolution of Bird-song" van Charles A. Witchell (1896) en daar
\end{abstract}


zijn er veel onder, die werkelijk gemakkelijk te herkennen zijn. Maar het motief, dat de Groote Lijster, ieder voorjaar in onze duinstreek doet weergalmen, is bij hem niet te vinden:

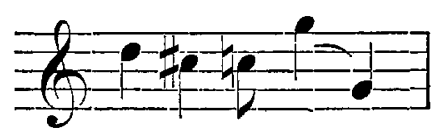

Het blauwborstje en de kneu zingen ook dikwijls duidelijke intervallen, maar zijn bij de snelheid van hun tempo moeilijk te volgen. Eenige zomers achtereen kon ik een kneutje observeeren, dat met groote zuiverheid en opgewektheid zong

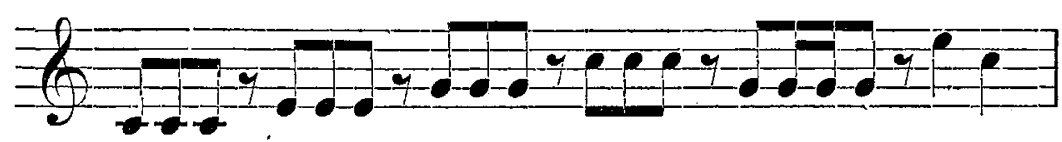

Het klonk als hoorngeschal. Ook van groenlingen, gorzen en wulpen zijn met bevredigend resultaat korte liedbrokjes in ons gewoon notenschrift te noteeren.

Over hèt algemeen echter zijn de resultaten nog al poover en dat bracht Dr. Alwin Voigt ertoe, om het aan te vullen met een nog al vernuftige notatie, bestaande uit stippen en streepjes, dicht opeen en ver van elkaar, dik en dun, in bogen en zigzaglijnen, die dan met elkaar een beeld geven van het lied. Zijn „Excursionsbuch zum Studium der Vogelstimmen" heeft ongetwijfeld de studie der vogelgeluiden zeer bevorderd. De beginner kan er weliswaar moeilijk mee terecht, maar de adept herkent in Voigt's schrift de hem bekende geluiden en zoo is vergelijking mogelijk en de weg gebaand tot vruchtbare gedachtenwisseling. Een vergelijking van den laatsten druk van het boekje met de eerste uitgave doet zien, dat het inderdaad de kennis der vogelgeluiden zeer heeft bevorderd.

Intusschen treedt bij de schrijfwijze van Voigt de melodie toch te veel op den achtergrond en dat bracht Hans Stadler en Cornell Schmitt ertoe om weer terug te keeren tot ons gewone notenschrift en dat zoo te wijzigen, dat ook de zeer groote en zeer kleine verschillen in toonhoogte konden worden uitgedrukt. Deze ijverige onderzoekers, die ook in ons land op Texel werkten, hebben de resultaten van hun waarnemingen vastgelegd in een aantal artikelen, die voornamelijk verschenen zijn in het "Journal für Ornithologie", maar ook in de "Ornithologische Monatshefte", in "British Birds" en in "Ardea", het orgaan der Nederlandsche Ornithologische Vereeniging. Het is te hopen, dat zij school maken en dat ook onderzoekers in andere landen hun werkwijze in toepassing brengen, want dan kunnen met zekerheid de reeds dikwijls vermelde locale verschillen in vogelzang worden vastgesteld.

Waarom zingt de vogel? Omdat hij het niet kan laten. Vrij algemeen is men de zienswijze toegedaan, dat de vogels hoofdzakelijk zingen uit sexueele aandrift, en men wijst dan gaarne op den nachtegaal, die alleen zingt gedurende den paar- en broedtijd. Ik heb echter wel nachtegalen hooren zingen in Augustus en jongen zelfs in September en het aantal der vogels, die in Augustus, September en October zingen is zeer groot, zonder dat er voor hen sprake is van paren of broeden. Nu kan men echter het begrip „sexueele invloed" zeer ruim nemen, zooals Freud doet, en er is wel kans op, dat de vogeltjes die in September zoo vroolijk doen, reeds sexueel-beinvloed zijn en vatbaar blijken voor rivaliteit. Trouwens bij watervogels beginnen de erotische vertooningen maanden voor den broedtijd en bij veel kraaien ook.

Intusschen hooren we dikwijls genoeg vogels zingen op oogenblikken, dat hun leeftijd of het jaargetijde de gedachte aan liefdezang vrijwel uitsluiten. In de eerste plaats hebben wij hier te letten op den zang van nestjongen. De hongerkreten zijn bekend genoeg. Sommige jongen schreeuwen alleen, wanneer ze reden hebben, om te denken, dat de ouden in de buurt zijn met voedsel, maar voor de rest van den tijd houden ze zich doodstil. Andere roeren zich ook tusschentijds en nog andere en wel in het bijzonder al onze spechtensoorten roepen zoowat den heelen dag, eerst onbestemd en half luid, later al duidelijker en duidelijker, tot zij vervallen in den echten spechtenroep, die ze verder hun geheele leven zullen laten hooren. Merkwaardig is het in dit verband, dat de oude, eenzaam rondzwervende bonte specht bij elk incident, dat met zijn voeding in verband staat, een vroolijk geroep doet 
hooren. Het is "tjedoek, tjedoek" als hij neerstrijkt in zijn den, vol rijpe kegels, hij roept alweer, als hij een dikkert gaat afplukken, roepend vliegt hij er mee weg en later proclameert hij alweer, dat het hem gelukt is, den kegel vast te klemmen in de schorsspleten van zijn eetboom. Al dien tijd is er geen andere specht te bekennen; hij monologiseert alleen voor zichzelf. Het goudhaantje doet hetzelfde en nog in sterker mate; ik heb in December een eenzaam vogeltje in mijn sparren aangetroffen, dat aanvankelijk de gewone lokroepen liet hooren, maar allengs verviel in een druk en aaneengeschakeld gezang, dat nog heel wat andere motieven bevatte dan de liefdezang van den paartijd. Zoo zingt ook de Vlaamsche gaai bij een overvloed van eikels en de vink in November als de grond vol ligt met beukenootjes.

Maar om op die nestjongen terug te komen, hun bestaan is niet een en al hanger en verscheidene zijn er, die reeds in het nest gelegenheid vinden, om den zang te beoefenen. Het is bekend, dat de jonge ooievaars al klepperen op het nest. Maar ik heb ook de nestjongen van zanglijster, Vlaamsche Gaai, Grauwe klauwier en rietzanger hooren zingen twee tot drle dagen, voordat zij uitvlogen en ongetwijfeld zijn er wel meer, die het doen, alleen is het niet gemakkelijk en nog al tijdroovend, om hieromtrent observaties te verzamelen.

Gedurende den trek wordt. veel gezongen en geroepen. Het laatste is natuurlijk van groot belang voor het bijeenhouden van den troep en het vinden van den weg, het eerste mag beschouwd worden als uiting van levenskracht en levenslust, van hooggestemdheid. Bovenaan staan in dit opzicht alweer de kraaien en met hen de ruiters en strandloopers. Ook de spreeuwen staan in dit opzicht zeer hoog, zij zingen en joelen voortdurend, als zij strijken door de aan bessen zoo rijke duinvalleien en ook wanneer zij 's avonds hun rust-. plaatsen opzoeken in de elzenboschjes of in het riet. Een zeer bijzondere vermelding verdienen hier ook de kneutjes, die al trekkende vaak buitengewoon mooi en aanhoudend zingen onder het vliegen en de boomleeuwerikken, die op zonnige Octoberdagen als brokjes gezang zuidwaarts zweven door ons duin. En al deze vogels met nog veel andere zingen ook, wanneer ze uren lang hun waanzinnige rondvlucht volhouden rondom het draailicht van den Brandaris. Dat angst en boosheid, spanning en vooral ontspanning aanleiding kunnen zijn tot hartstochtelijk en zelfs zeer langdurig gezang blijkt 's winters gedurig bij het onderling verkeer van winterkoninkjes en roodborstjes met katten, ratten, hermelijnen en wezels en ook bij het invallen van dooi na strenge vorst of sneeuwstormen. Intusschen gaat dan in Januari reeds stellig het erotisch moment meetellen.

Ik vraag mij af, of het toeval is, dat de hierboven genoemde zingende nestjongen: Zanglijster, Vlaamsche Gaai, Grauwe Klauwier en Rietzanger meteen meetellen onder de knapste nabootsers. Het zou dan zaak zijn, om te onderzoeken of de Spreeuw, de Spotvogel en het Blauwborstje ook van. die vroeg-zingende jongen hebben. Nabootsing komt bij een zeer groot aantal vogels voor, bebalve dit zevental kunnen we nog noemen de roodstaart, roodborst, merel, groote lijster, de leeuwerik, boomklever, nachtegaal, de grasmusch en al de leden van de kraaienfamilie, waarin dan op de Vlaamsche gaai de notekraker moet volgen. Charles Witchell heeft in zijn Evolution of Bird-song zeer veel aandacht geschonken aan imitatie en Stadler en Schmitt hebben in het "Reichenow-Festschrift" zeer terecht gewezen. op de omstandigheid, dat veel van wat wij als imitatie waarnemen, een secundair verschịnnsel is, n.l. dat de jonge vogels de nagebootste geluiden niet van de oorspronkelijke virtuosen, maar van hun eigen ouders of kornuiten hebben overgenomen. Zij vergelijken dan de imitatie-geluiden met de vreemde woorden, die gangbaàr geworden zijn in onze taal en die gebruikt worden door lieden, die de vreemde taal zelve wellicht nooit gehoord hebben. Stellig komt dit voor, maar even zeker is het, dat wị dikwijls genoeg de gelegenheid vinden, om waar te nemen, dat een imitator een voor hem nieuw geluid direct overneemt van de oorspronkelijke bron of dat hij imiteerend reageert op het oorspronkelijk geluid. Zoo kan men den zanglijster zijn zang hooren onderbreken, om een voorbijvliegende wulp te begroeten, en zoo heb ik een roodstaartje aanhoudend en onverstoorbaar een schildvink hooren beantwoorden. Spreeuw en Vlaamsçhe gaai zijn zeer bekwaam in het nabootsen van andere 
dan vogelgeluiden, terwijl stadsmerels niet ongevoelig zijn voor de prestaties van straatjongens, straatorgels en kerkmuziek. Hun geval sluit direct aan bij de opzettelijke zangoefeningen, die culmineeren in den Duitschen schoenmaker en zijn goudvinken, maar die hier buiten beschouwing blijven. In ieder geval speelt het nabootsingsinstinct een zeer groote rol bij de ontwikkeling van den vogelzang. Een bedoeling heeft het niet. Nog altijd ontmoet men de bewering, dat de grauwe klauwier kleine zangertjes tot zich zou lokken, door hun zang na te bootsen, om ze dan te bemachtigen. 't Is niet onmogelijk, dat zoo iets een. enkele maal is gebeurd, maar. wanneer we den klauwier aantreffen, nabootsende wulp, griel: of zilvermeeuw, dan liggen dergelijke bedoelingen toch zeker.heel ver. Zeer belangwekkend blijft evenwel de vraag, in hoeverre de nabootsing van natuurgeluiden den vogelzang heeft: verrijkt: het ruischen van de branding en van den waterval, het neertinkelen van dikke onweersdroppels op het spiegelgladde meer, het knersen en piepen van langs elkaar schurende boomstammen, het stadig ritselen van het dorre rietblad in den strakken noordooster. Er zijn wel vogelgeluiden, die daarmee overeenstemmen of harmonieeren, maar wij moeten. met de grondslagen der vogelzang-studie nog veel verder zijn, eer wij in dezen tot een definitief oordeel kunnen geraken. De weg er heen is echter een der aangenaamste, die een bioloog kan bewandelen.

Bloemendaal, 28 November 1918. 